\title{
Serological evidence of West Nile Virus infection among humans in the southern Provinces of Morocco
}

\author{
Hicham El Rhaffouli ${ }^{1}$, Idriss Lahlou-Amine ${ }^{1}$, Chafiqua Lotfi ${ }^{2}$, Abdellilah Laraqui ${ }^{1}$, Tahar Bajjou ${ }^{1}$, Ouafaa \\ Fassi-Fihri ${ }^{3}$, Mehdi El Harrak ${ }^{2}$ \\ ${ }^{1}$ University Mohammed V-Souissi, Faculty of Medicine and Pharmacy, Mohammed V Military Teaching Hospital, \\ Biosafety Level 3 and Research Laboratory, Rabat, Morocco \\ ${ }^{2}$ Laboratoire Bio-Pharma, Rabat, Morocco \\ ${ }^{3}$ Hassan 2 Agronomic and Veterinary Institute, Rabat, Morocco
}

\begin{abstract}
Introduction: The objective of this study was to determine the prevalence of West Nile Virus infection in the southern provinces of Morocco. Methodology: A total of 250 sera, collected during 2012 in the province of Dakhla, were analyzed by microneutralisation assay.

Results: WNV-neutralizing antibodies were detected in 13 samples (5.2\%). The participants with WNV-specific antibodies were significantly younger than the rest of the population $(\mathrm{p}=0.009)$. The positivity rate was higher among women $(6.3 \%)$ than men $(3.6 \%)(\mathrm{p}=0.26)$.

Conclusions: This is the first serological evidence of WNV infection among humans in the southern provinces of Morocco.
\end{abstract}

Key words: West Nile Virus; serology; virus-neutralization test; WNV strain 96-111; Morocco

J Infect Dev Ctries 2013; 7(12):999-1002. doi:10.3855/jidc.3399

(Received 11 February 2013- Accepted 14 April 2013)

Copyright (C) 2013 El Rhaffouli et al. This is an open-access article distributed under the Creative Commons Attribution License, which permits unrestricted use, distribution, and reproduction in any medium, provided the original work is properly cited.

\section{Introduction}

Moroccan officials confirmed outbreaks of West Nile Virus (WNV) infection in horses in 1996 [1], 2003 [2], and 2010 [3], with dozens of confirmed cases. Nevertheless, only one case of human infection was reported in 1996 [2]. However, a serological study confirmed the occurrence of WNV infection among humans with prevalence rates ranging from $4.7 \%$ to $18.8 \%$ [4]. All these data were from northern Morocco, which is the wettest region of the country and is regarded as the endemic area for WNV infections.

In the Sahara, a recent study demonstrated that $29 \%$ of the dromedaries of this region were positive for WNV antibodies [5]. In addition, O. Fassi-Fihri in a personal communication on July 10, 2012 found that several wild birds tested RT-PCR positive for WNV in the Sahara region, particularly among cormorants in the vicinity of Dakhla and Boujdour, in 2008.

Such data suggests a local circulation of WNV and a risk of human infections. To assess this risk, we conducted a serological investigation in the province of Wad-ad-Dahab in the extreme south of Morocco, located about 1,700 km from Rabat (Figure 1).

\section{Methodology}

A total of 250 anonymised sera from leftover diagnostic samples taken between March and June 2012 were obtained from the biochemistry laboratory in the regional hospital of Dakhla. The data available for these samples included age, sex, recent medical history, and home residence of patients. In this study, participants permanently residing in the province of Wad-ad-Dahab and not suffering from any chronic or serious illness were selected. Serum was stored at $-20^{\circ} \mathrm{C}$ until tested. Just before testing, serum samples were heated at $56^{\circ} \mathrm{C}$ for 30 minutes. The samples were screened for the neutralizing antibody against the equine WNV strain, Morocco 96-111 (accession number: AY 701412), by using a micro virusneutralization test in 96-well plates and an adaptation of a previously described method [6,7]. Dilutions of the test serum $(50 \mu \mathrm{L})$ were incubated with one hundred $50 \%$ tissue culture infectious doses of the virus in the same volume $(50 \mu \mathrm{L})$ for one hour at $37^{\circ} \mathrm{C}$ in Dulbecco minimum Eagle medium. Next, $150 \mu \mathrm{L}$ $\left(10^{5}\right.$ cells $\left./ \mathrm{mL}\right)$ of a Vero cell suspension with $5 \%$ fetal calf serum was added. This mixture was incubated for five to six days at $37^{\circ} \mathrm{C}$ until cytopathic effects were observed in a negative control well containing a $50 \%$ 
tissue culture infectious dose of virus. Serum samples were screened in duplicate at dilutions of 1:6, 1:18, and 1:54. Samples that neutralized the virus characterized by the absence of cytopathic effects - at one of the dilutions tested were retested in four replicates to confirm the results. The samples were titrated by testing six serial dilutions ranging from 1:6 to $1: 1,458$. Titers were calculated using the SpearmanKärber method [8]. Titers $>18$ were considered positive.

\section{Results}

The ages of participants ranged between six months and 80 years of age, with a mean of 38 years ( $\mathrm{SD} \pm 13$ years); $59 \%$ were men and $41 \%$ were women (Table 1). Of the 250 samples, WNV-neutralizing antibodies were detected in $13(5.2 \%)$, including 11 participants living in the vicinity of Dakhla, and 2 living in Boujdoure.

The participants with WNV-specific antibodies were significantly younger than the rest of the population studied (26 versus 37 years, $\mathrm{p}=0.009$ ). Two samples were obtained from young children 6 and 24 months of age ten days after consultation for febrile syndrome. While the positivity rate was higher among women $(6.3 \%)$ than men $(3.6 \%)$, the differences were not statistically significant $(p=0.26)$. Titers determined by the micro virus-neutralization test ranged from 24 to 501 (median $=72, \mathrm{SD} \pm 42$ ).

\section{Discussion}

Since the emergence of WNV in Morocco in 1996 [1], several studies have been undertaken to measure the frequency of antibodies against the virus among animals in the southern regions of the country $[5,9,10]$, but to our knowledge, there were no seroprevalence data for WNV antibodies in humans in this region. Thus, we evaluated the prevalence of WNV-specific antibodies in the vicinity of Dakhla, the capital of the Wad-ad-Dahab region. Dakhla is a desert region with an area of over $160,000 \mathrm{~km}^{2}$ situated on bird migration routes between Africa and Europe, with a population of about 65,000 residents in 2004 [11].

The technique used in this study was based on the principle of virus neutralization; the plaque reduction neutralization test still considered the gold standard WNV serological test. Moreover, this test has excellent agreement with other serological tests such as the indirect enzyme-linked immunosorbent assay and the indirect fluorescent antibody test [12].

The seroprevalence rate obtained in our study was higher than that reported in the region of Meknes, but
Figure1: Map of Morocco with administrative subdivision highlighting the location of the study area (in brown), the regions of Kenitra (in red), Rabat (in pink), Meknes (in green) and the geographical distribution of WND cases occurred in 2003 (blue squares) and in 2010 (black squares) epizooties $[2,3]$.

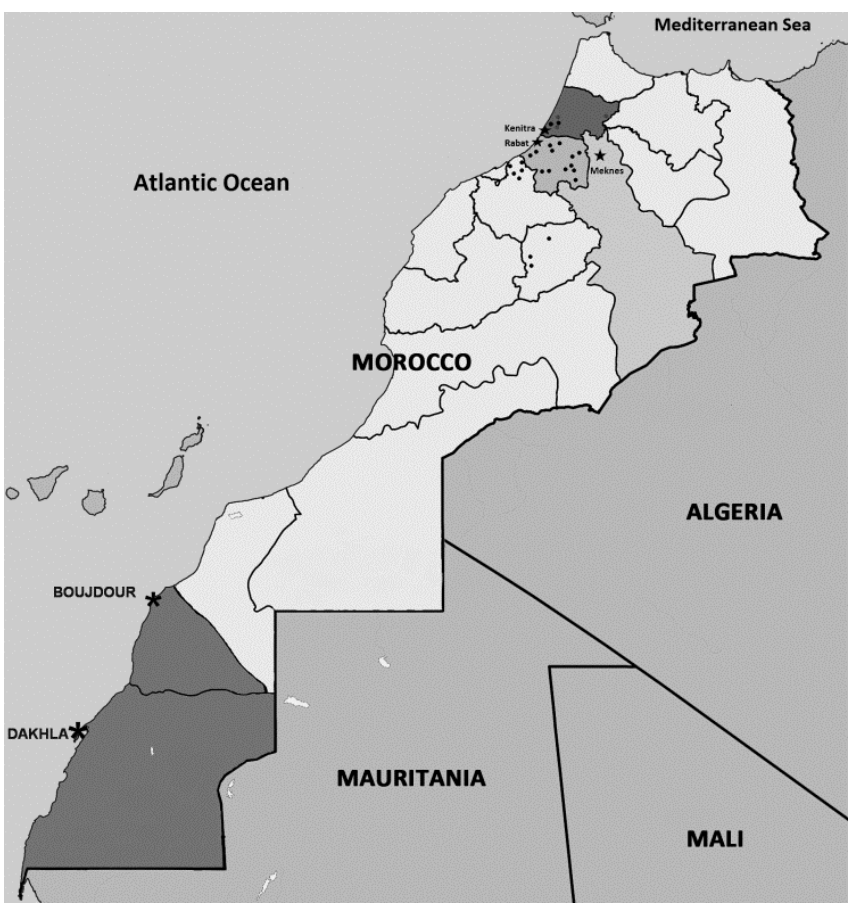

it was lower than the rates found in the regions of Rabat and Kenitra (Table 2) [4]. In addition, the antibody titers found among participants from Dakhla were higher than those reported from Meknes and Rabat, but lower than those found in Kenitra. This may be the result of re-infection with WNV from multiple mosquito bites.

The results obtained in this study strongly suggest that the population of this region has been in contact with WNV. We can assume that this contact could occur during trips to endemic areas of the kingdom, but the detection of WNV-specific antibodies among young children between 6 and 24 months of age from the Dakhla region suggests a recent local circulation of WNV in the region. The origin of these antibodies can be either infectious or due to passive transmission of maternal antibodies. However, it is very unlikely that maternal antibodies can be detected at 24 months of age. Despite the fact that current data on potential vectors of WNV are not available for the region of Dakhla, our observations suggest that locally occurring mosquitoes could belong to the genus Culex. However, further entomological studies should answer this critical question. 
Table 1: Demographic characteristics of participants

\begin{tabular}{lccc}
\hline Characteristic & Total & $\begin{array}{c}\text { Participants with WNV-specific } \\
\text { antibodies positive, n (\%) }\end{array}$ & $\begin{array}{c}\text { Participants with WNV-specific } \\
\text { antibodies negative, }\end{array}$ \\
\hline Number of patients, $\mathrm{n}(\%)$ & 250 & $13(5.2 \%)$ & $237(94.8 \%)$ \\
Number of females, n (\%) & $111(44.4 \%)$ & $7(6.3 \%)$ & $104(93.7 \%)$ \\
Number of males, n (\%) & $139(55.6 \%)$ & $5(3.6 \%)$ & $134(96.4 \%)$ \\
Mean age and standard deviation & $38 \pm 13$ & $26 \pm 14$ & $37 \pm 13$ \\
\hline
\end{tabular}

Table 2: Seroprevalence of West Nile Virus infection in the human population of four regions of Morocco

\begin{tabular}{cccccc}
\hline Region & No positive sera/ no tested (\%) & Median & $\begin{array}{c}\text { Weak titers } \\
\mathbf{1 : 1 8} \text { to 1:80 }\end{array}$ & $\begin{array}{c}\text { Intermediate titers } \\
\mathbf{1 : 8 0} \text { to 1:320 }\end{array}$ & $\begin{array}{c}\text { High titers } \\
\mathbf{1}: \mathbf{3 2 0}\end{array}$ \\
\hline Dakhla & $13 / 250(5.2 \%)$ & $1: 72 \pm 42$ & $9(69.2 \%)$ & $3(23.1 \%)$ & $1(7.7)$ \\
Meknes [4] & $7 / 150(4.7 \%)$ & $1: 54 \pm 42.5$ & $5(71.4 \%)$ & $1(14.3 \%)$ & $1(14.3 \%)$ \\
Rabat [4] & $24 / 200(12 \%)$ & $1: 54 \pm 31$ & $22(91.7 \%)$ & $1(4.2 \%)$ & $1(4.2 \%)$ \\
Kenitra [4] & $28 / 149(18.8 \%)$ & $1: 95 \pm 72$ & $19(67.9 \%)$ & $3(10.7 \%)$ & $6(21.4 \%)$ \\
\hline
\end{tabular}

The high seroprevalence rate among young participants could be related to their socio-economic activities (working outside and leisure) that expose them to mosquito bites in relation to the older subjects. Moreover, these young people are more likely to adopt a European style of clothing, which covers much less the body and exposes more skin, and as a consequence, is less protective than traditional clothing worn by older people. The higher prevalence rate among women could be related to an overexposure to risk, especially in oasis regions, where most of a housewife's tasks such as milking and collecting? drinking water occur near watering points with high concentrations of animals, birds, and mosquitoes.

While the WNV strains that circulated in the northern part of the country during 1996 and 2003 were found to belong to WNV lineage 1, clade 1a [2], which most often causes mild and self-limiting illnesses, there are no data about the strain circulating in southern Morocco or the pathogenicity of these strains. The absence of clinical cases reported is probably due a low suspicion index for WNV infection, a disease that often remains poorly identified by clinicians and for which very few laboratories in Morocco are able to diagnose.

\section{Conclusion}

The current study suggests the presence of a local circulation of WNV in the region of Dakhla. This is the first serological evidence of WNV infection among humans occurring in the Sahara in the southern provinces of Morocco. Thus, it appears that WNV is more widespread in the country than had been thought before, and a program of monitoring and surveillance that includes all of Morocco should be established.

\section{References}

1. El Harrak M, Le Guenno B, Le Gounon P (1997) Isolation of West Nile virus in Morocco. Virologie 1: 248-249.

2. Schuffenecker I, Peyrefitte CN, El Harrak M, Murri S, Leblond A, Zeller H (2005) West Nile virus in Morocco, 2003. Emerg Infect Dis 11: 306-309.

3. Office national de sécurité sanitaire des produits alimentaires (2010) Informations Zoo sanitaires Nationales, Aout 2010 Available from: http://www.onssa.gov.ma/onssa/fr/doc_pdf/Sit_national-082010.pdf. Accessed 14 january 2013]

4. El Rhaffouli H, El Harrak M, Lotfi C, El Boukhrissi F, Bajjou T, Laraqui A, Hilali F, Kenfaoui M, Lahlou-Amine I (2012) Serologic evidence of West Nile virus infection among humans, Morocco. Emerg Infect Dis 18: 800-801.

5. El-Harrak M, Martín-Folgar R, Llorente F, FernándezPacheco P, Brun A, Figuerola J, Jiménez-Clavero M A (2011) Rift Valley and West Nile virus antibodies in camels, North Africa. Emerg Infect Dis 17: 2372-2373.

6. Swanepoel R, Struthers J K, Erasmus M J, Shepherd S P, McGillivray G M (1986) Comparison of techniques for demonstrating antibodies to Rift Valley fever virus. J Hyg 97: 317-329.

7. Weintgartl HM, Drebot MA, Hubalek Z, Halouzka J, Andonova M, Dibernardo A, Cottam-Birt C, Larence J, Marszal P1 (2003) Comparison of assays for the detection of West Nile virus antibodies in chicken serum. Can J Vet Res 67:

$128-132$

http://www.ncbi.nlm.nih.gov/pmc/articles/PMC227040/?tool $=$ pubmed.

8. Kärber G (1931) Beitrag zur kollektiven Behandlung pharmakologischer Reihenversuche. Arch Pharmacol 162: 480483.

9. Figuerola J, Baouab RE, Soriguer R, Fassi-Fihri O, Llorente F, Jimenez-Clavero MA (2009) West Nile virus antibodies in wild birds, Morocco, 2008. Emerg Infect Dis 15: 1651-1653. 
10. Touil N, Cherkaoui Z, Lmrabih Z, Loutfi C, Harif B, El Harrak M (2012) Emerging viral diseases in dromedary camels in the Southern Morocco. Transbound Emerg Dis 59: 177-182.

11. Haut-Commissariat au plan, Recensement général de la population et de l'habitat 2004 French. Available from: http://www.hcp.ma/Recensement-general-de-la-population-etde-1-habitat-2004_a633.html. Accessed 14 january 2013]

12. Niedrig M, Sonnenberg K, Steinhagen K, Paweska JT (2007) Comparison of ELISA and immunoassays for measurement of IgG and IgM antibody to West Nile virus in human sera against virus neutralization. J Virol Methods 139: 103-105.

\section{Corresponding author}

Hicham El Rhaffouli

Laboratoire de Recherche et de Biosécurité P3

Hôpital Militaire D'Instruction Mohamed V

Hay Riad, Rabat, Morocco

Phone: 00212537713220 / 00212661433439

Fax: 00212537713220

Email: elrhaffoulihicham@live.fr / h.elrhaffouli@um5s.net.ma

Conflict of interests: No conflict of interests is declared. 